\title{
Climate Change Impacts on Environmental Hazards on the Great Hungarian Plain, Carpathian Basin
}

\author{
Gábor Mezősi · Teodóra Bata · Burghard C. Meyer • \\ Viktória Blanka · Zsuzsanna Ladányi
}

Published online: 29 May 2014

(C) The Author(s) 2014. This article is published with open access at Springerlink.com

\begin{abstract}
The potential impacts of climate change on the Great Hungarian Plain based on two regional climate models, REMO and ALADIN, were analyzed using indicators for environmental hazards. As the climate parameters (temperature, precipitation, and wind) will change in the two investigated periods (2021-2050 and 2071-2100), their influences on drought, wind erosion, and inland excess water hazards are modeled by simple predictive models. Drought hazards on arable lands will increasingly affect the productivity of agriculture compared to the reference period (1961-1990). The models predict an increase between $12.3 \%$ (REMO) and $20 \%$ (ALADIN) in the first period, and between $35.6 \%$ (REMO) and $45.2 \%$ (ALADIN) in the second period. The increase of wind erosion hazards is not as obvious $(+15 \%$ for the first period in the REMO model). Inland excess water hazards are expected to be slightly reduced ( -4 to $0 \%$ ) by both model predictions in the two periods without showing a clear tendency on reduction. All three indicators together give a first regional picture of potential hazards of climate change. The predictive model and data combinations of the regional climate change models and the hazard assessment models provide insights into regional and subregional impacts of climate change and will be useful in planning and land management activities.
\end{abstract}

Keywords Carpathian Basin - Drought . Great Hungarian Plain · Inland excess water · Regional modeling $\cdot$ Wind erosion

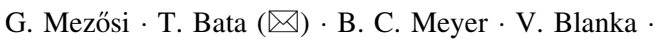

Z. Ladányi

Department of Physical Geography and Geoinformatics, University of Szeged, Egyetem u. 2-6, Szeged 6722, Hungary

e-mail: bteodora@geo.u-szeged.hu

\section{Introduction}

Climate change strongly impacts the Carpathian Basin. Many natural hazards-for example drought (Blanka et al. 2013), inland excess water (Rakonczai et al. 2011), and wind erosion (Mezősi, Blanka, et al. 2013)—cause social, economic, and environmental problems. Drought is increasingly a worldwide problem due to global climate change. The lack of water during drought periods is harmful to all living organisms, including humans, causing restrictions in industrial and communal water use and reductions in agricultural yields (Warrick et al. 1975; Maracchi 2000; Svoboda et al. 2002; Zeng 2003; Lei et al. 2011; Ye et al. 2012; Lin et al. 2013). In the Carpathian Basin drought is one of the most severe environmental hazards (Bakonyi 2010; Pálfai and Herceg 2011; Bihari 2012; Gosic and Trajkovic 2013; WMO 2013) that occurs every 3-5 years. Excess water affects mostly lowland areas, causing damages to agriculture, soil structure, and inundated urban areas (Likens 2009; Rakonczai et al. 2011; van Leeuwen 2012; Julian et al. 2013; Shi et al. 2013). Excess water occurs regularly in the Carpathian Basin, typically at the end of winter and in spring, but during summer as well every 2-4 years. The extent strongly varies between years, affecting 200-400 thousand hectares of agricultural lands in Hungary (10-20\% of the arable lands on the Great Hungarian Plain, southeast Hungary). Due to global warming and changing precipitation conditions, wind erosion on arable lands has become an important natural hazard in the world, confirmed by the increasing number of wind erosion modeling assessments (for example, Australia: Woodruff and Siddoway 1965; Webb et al. 2006; America: Fryrear et al. 1998; Hagen 2004; Europe: Klik 2004; Munson et al. 2011; Asia: Shao et al. 2002; Funk et al. 2004; Li et al. 2005; Fratini et al. 2009; Africa: Sterk 2003; Toure et al. 
2011). The incidence of wind erosion and the rate of damage are determined by several environmental factors, such as soil texture, lithology, climate, vegetation, and human land use (agricultural techniques). According to Lóczy et al. (2012) $26.5 \%$ of the Carpathian Basin is affected strongly or moderately by wind erosion.

The spatial extension of different natural hazards has been determined in Hungary with adequate accuracy (Blanka et al. 2013; Mezősi, Blanka, et al. 2013). However, due to the uncertainty of future hazard occurrences their cumulative effect is hard to predict. Such assessments are available only for smaller natural units, and they are not quantitative measures (Szabó et al. 2008).

The highest impacts of drought, inland excess water, and wind erosion are occurring in the lowland areas of Hungary, especially on the Great Hungarian Plain. Therefore, this research focuses on this area. Flood hazards are also an important problem here. However, given river regulation and flood protection works, floods are normally limited to the regulated floodplain. Due to these water management practices and other influencing factors (land use and the construction of dams in the upper section) at catchment scale, it is difficult to assess the risks and consequences of floods without assessing the surrounding mountainous areas (Mezősi, Meyer, et al. 2013); thus this hazard was excluded from the assessment.

In the last two centuries global climate change has become increasingly obvious and further warming is expected. On the basis of the climate model simulations, future warming is accompanied by changing precipitation conditions, causing more frequent and more serious natural disasters, which lead to financial and environmental losses (IPCC 2007). Based on the climate model simulation, in the Carpathian Basin increasing temperatures $\left(+1.5^{\circ} \mathrm{C}\right.$ for 2021-2050, $+3.5^{\circ} \mathrm{C}$ for 2071-2100) (Szabó et al. 2011) are projected. The change in annual precipitation simulated by model experiments is not significant. However, intraannual distribution will be modified: $20 \%$ increase of precipitation in the winter half of the year and $20 \%$ decrease in the summer half of the year are projected (Bartholy et al. 2011).

The aim of the research is to analyze the changes in spatial extension and severity of natural hazards during the twentyfirst century on arable lands on the Great Hungarian Plain. During the analysis only the climatic aspects of the change of the hazards were assessed based on regional climate model simulations. These models give climate projections for two future periods of 30 years and the hazard assessment refers to the same periods. Integrated analysis of the hazards was not carried out because of the complexity of the problem. The results of the analysis can be useful to spatial planning, since information about the regional and local impacts of the hazards is of interest to branches of planning and risk prevention (Meyer et al. 2009). Future assessment of natural hazards meets the public demand to determine the future trends of the changes.

\section{Study Area}

The Great Hungarian Plain is situated in the middle of the Carpathian Basin, in southeast Hungary (Fig. 1). The Great Hungarian Plain is a lowland area (75-180 m above sea level) with low relative relief. The surface is covered by 20-400 m unconsolidated sandy and silty sediments, mostly of Pleistocene fluvial, lacustrine, or eolian origin (Mezősi 2011). More than $60 \%$ of the area is arable land, where the vegetation cover is changing in seasonal schedules according to the agricultural crop rotation (the main crops are wheat and maize). This high share of arable land in total area is unique in Europe (HCSO 2011). The annual mean precipitation is 500-550 $\mathrm{mm}$ and the average temperature is $10-11{ }^{\circ} \mathrm{C}$ (Péczely 1998). The monthly average wind speed is highest $\left(3.5 \mathrm{~m} \mathrm{~s}^{-1}\right)$ in the spring, in March and April (Péczely 1998) when the risk of wind erosion is especially high.

The Great Hungarian Plain in Hungary benefits from these natural features that provide favorable conditions for agriculture: fertile plains, an advantageous climate, availability of water. Under these environmental conditions the most important natural hazards are connected to climatic variability, the low relief, the orographic characteristic (basin situation), the land cover types (the main land cover types are arable land, pasture, and broad-leaved forest), and land use practices (for example, agriculture, grazing or deforestation). Natural hazards in this area are caused by the irregular water balance, since annual precipitation is highly variable - the observed minimum value was $203 \mathrm{~mm}$ (at Szeged meteorological station in 2000), the maximum was 1,555 mm (at Miskolc-Lillafüred-Jávorkút meteorological station in 2010) (HMS 2013). In humid years excess water can induce floods and inland excess water inundations, while in dry years lack of water can cause drought and increase wind erosion events. These hazards highly affect the natural environment and land owners of the region. The economic loss caused by these natural hazards can reach 2-6\% of the GDP, depending on the duration, intensity, and occurrence and co-occurrence of different hazards (Bakonyi 2010). Because of drought the average yield of maize showed a $50 \%$ decrease in 2007 (3.7 $\mathrm{t} \mathrm{ha}^{-1}$ ) compared to the previous years (Széll and Dévényi 2008). The drought in May 2003 caused serious damages (15-80\%) when $90 \%$ of the area was under cereal production ( 1 million ha of wheat, 0.7 million ha of other cereal) (Hazafi 2003).

Wind erosion induced agricultural damage can be as high as $10-15 \%$ of total environmental agro-economic 


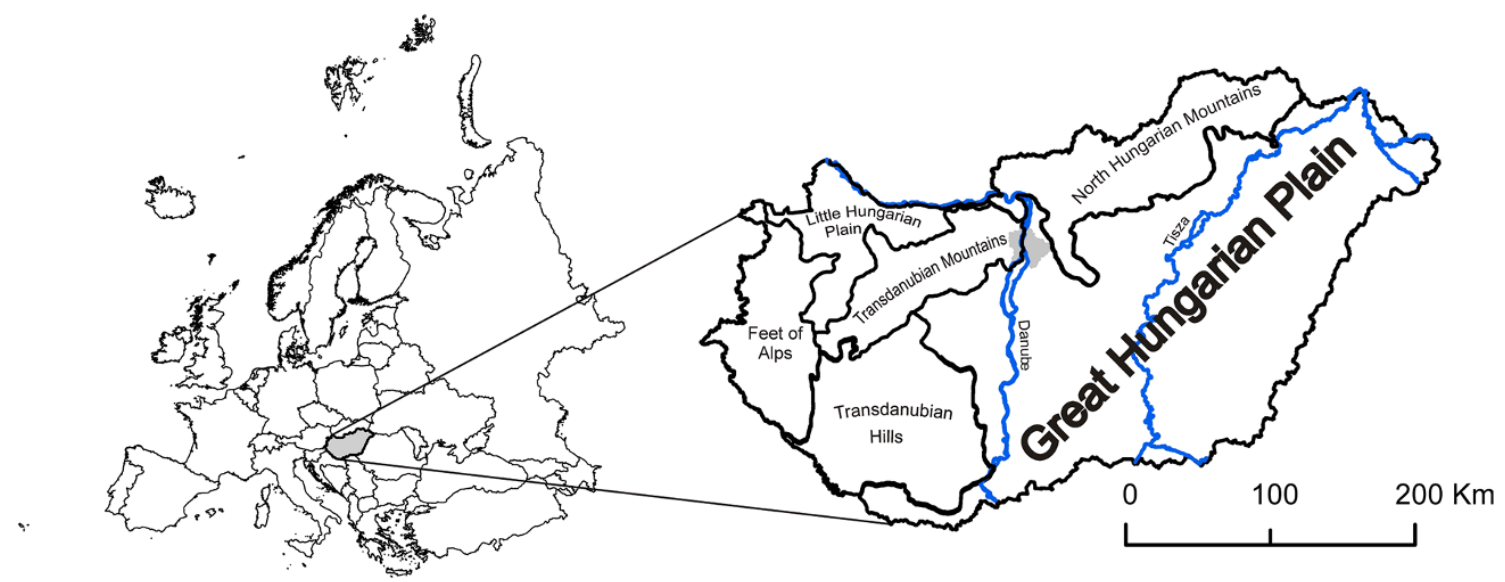

Fig. 1 Location of the study area in Hungary

damage in Hungary (Szabó et al. 1994; Lóczy et al. 2012). In the case of inland excess water, on average 110,000 ha of land are temporarily inundated annually, usually in spring. However, since 1935 there have been 13 years in which more than 200,000 ha of land were inundated (van Leeuwen 2012).

\section{Methods}

The impacts of climate change on environmental hazards on the Great Hungarian Plain were assessed by calculating the future changes of the most important natural hazards of the region (drought, wind erosion, and inland excess water), based on regional climate model simulation data. Since the greatest economic damages usually occur in agriculture due to these hazards, this assessment is focused on arable lands.

\subsection{Calculation of Climate Data}

For assessing future climate change, simulation data of two regional climate models, REMO and ALADIN, were used. These models use the A1B scenario to model anthropogenic climate forcing (Bartholy et al. 2008), which represents the average changes of greenhouse gas emissions (Nakicenovic and Swart 2000). These climate models provide daily temperature and precipitation change data for two future periods, 2021-2050 and 2071-2100. The resolution of the climate data was $0.22^{\circ}$ (approximately $25 \mathrm{~km}$ ). The model simulations were run by the Numerical Modelling and Climate Dynamics Division of the Hungarian Meteorological Service. From these data, average yearly and monthly data were calculated for the two 30 -year periods.

\subsection{Assessment of Natural Hazards}

The most likely environmental hazards associated with climate change on the Great Hungarian Plain are the changes in frequency and seriousness of drought, the changes in intensity of wind erosion, the changes in frequency and seriousness of inland excess water, and the changes in frequency and seriousness of flood (Mezősi, Meyer, et al. 2013). Due to their actual importance three natural processes were considered during the analysis: droughts, soil erosion by wind, and inland excess water. These processes represent the most significant environmental hazards for land use on the Great Hungarian Plain as well as in Hungary as a whole (Szabó et al. 2008).

Droughts, in general, are a natural phenomenon in the study area, though human activity can have a high indirect influence on their severity, especially through land use (for example, inadequate agro-techniques, water overuse), and in the future droughts are expected to become more serious because of climate change. To evaluate the magnitude of the changes of drought hazard in the future the Pálfai Drought Index (PaDI) was applied (Pálfai and Herceg 2011). This index uses monthly temperature (AprilAugust) $(T)$ and monthly precipitation $(P)$ data with a weighting factor $(w)$ expressing the importance of the months in the evolution of drought (Table 1). The index focuses on drought occurring in the vegetation growth period, since it provides one numerical value for one agricultural year.

Wind erosion hazard was modeled using the key factors of soil erodibility, vegetation cover, and wind erosivity in the most important spring period (March and April) as proxies. The wind erosion calculation was based on fuzzy logic. By applying fuzzy logic, each unit was assigned a value between 0 and 1 , where 0 means not sensitive and 1 means the maximum sensitivity to wind erosion. Thus 0.4 means that 
the area is $40 \%$ sensitive; consequently, this area can be regarded as somewhat insensitive (Mezösi, Blanka, et al. 2013). To assess the future changes of wind erosion hazard the changes of the climate parameters were applied for the two periods (2021-2050 and 2071-2100). The real wind erosion hazard depends on other factors beside the climate parameters (vegetation cover, agricultural techniques). However, the future trend of these parameters is hard to assess. The future changes of the climate parameters were assessed by calculating the climatic factor of the Wind Erosion Equation WEQ (Klik 2004). This index uses monthly temperature $(T)$, monthly precipitation $(P)$ and monthly average wind speed data (Table 1).

Inland excess water also regularly affects the study area. Several unfavorable natural (for example, meteorological, hydrological, geomorphological, pedological) and anthropogenic factors (for example agro-techniques) contribute to its occurrence at the same time (Bozán et al. 2009). To assess the future changes of inland excess water hazards, the Humidity Index (HUMI) was applied. This index uses the precipitation data $(p)$ between November and April and the potential evapotranspiration (PET) from November to April (Table 1). Evapotranspiration is determined by precipitation and temperature data that were modeled by regional climate models for future periods.

The assessment focused on arable lands (about $30,000 \mathrm{~km}^{2}$ ), since $84 \%$ of the Great Hungarian Plain is used by agriculture, mostly arable lands. Indexes characterizing drought hazard (PaDI), wind erosion sensitivity, and inland excess water hazard (HUMI) (Table 1) were calculated for a base period (1961-1990) and two future periods (2021-2050 and 2071-2100) based on REMO and ALADIN regional climate model simulation data. The hazards were evaluated by the changes between the reference and the future periods for both models. The rate of changes was classified into $5 \%$ intervals. The area of land in each interval was calculated in the percentage of the total area of arable lands. The dataset was normalized by cutting out the extreme values (where area is less than $1 \%)$. The dataset contains small patches that result in inaccurate values when overlayed with the climate dataset. These errors were avoided by excluding the extreme values from the analysis.

\section{Results}

The spatial extension and severity of drought, wind erosion, and inland excess water hazards are assessed separately during the twenty-first century on arable lands.

\subsection{Changes in Drought Hazard}

The drought hazard in the future shows an increasing tendency, according to model simulations. For the first period (2021-2050) the average rate of increase in the drought index $(\mathrm{PaDI})$ is projected to be lower $(12 \%$ in the

Table 1 The calculation methods of the assessed natural hazards

\begin{tabular}{|c|c|c|}
\hline Hazards & Parameters & Calculation \\
\hline \multirow[t]{5}{*}{ Drought } & Precipitation & PaDI—Palfai drought index (Pálfai 2002, 2004) \\
\hline & Temperature & $\mathrm{PaDI}=\left[\sum_{i=\mathrm{Apr}}^{\mathrm{Aug}} T_{i} / 5 * 100\right] / \sum_{i=\mathrm{Oct}}^{\mathrm{Sept}} P_{i} * w_{i}$ \\
\hline & & $T_{i}$-monthly average temperature, ${ }^{\circ} \mathrm{C}$ \\
\hline & & $P_{i}$-monthly precipitation, $\mathrm{mm}$ \\
\hline & & $w_{i}$-weighting factor \\
\hline \multirow[t]{6}{*}{ Wind erosion } & Soil & $\begin{array}{l}\text { Wind erosion hazard map: erodibility of soil, climate factor (March and } \\
\text { April), vegetation cover (March and April) (Mezősi, Blanka, et al. 2013) }\end{array}$ \\
\hline & Vegetation cover $C$ factor (wind & Calculation of climate $(C)$ factor: $C=386^{*} u^{3} /(\mathrm{PE})^{2}$ \\
\hline & $\begin{array}{l}\text { speed, precipitation, } \\
\text { temperature) }\end{array}$ & $\begin{array}{l}u \text {-average monthly wind speed, PE: Thornthwaite (1948) precipitation- } \\
\text { effectiveness index }\end{array}$ \\
\hline & & $\mathrm{PE}=3.16^{*} P_{i} /\left(1.8 T_{i}+22\right) 10 / 9$ \\
\hline & & $P_{i}$-monthly precipitation, $\mathrm{mm}$ \\
\hline & & $T_{i}$-monthly average temperature, ${ }^{\circ} \mathrm{C}$ \\
\hline \multirow[t]{4}{*}{ Inland excess water } & Precipitation & HUMI = Humidity index \\
\hline & Temperature & $\mathrm{HUMI}=(p / \mathrm{PET})^{0.5}$ \\
\hline & & $p$-sum of the precipitation in November-April (winter period), $\mathrm{mm}$ \\
\hline & & PET_-potential evapotranspiration in November-April (winter period), $\mathrm{mm}$ \\
\hline
\end{tabular}


case of the REMO and $20 \%$ in the case of the ALADIN model) than for the second period (2071-2100), when $35 \%$ increase is projected in the case of the REMO and $45 \%$ in the case of the ALADIN model (Table 2).

The normalized dataset shows that on the basis of the REMO model simulation, in the first period (2021-2050), $59 \%$ of arable lands on the Great Hungarian Plain will be affected by a slight (10-15\%) increase of the drought hazard and on $24 \%$ of arable lands a $15-20 \%$ increase of the hazard is expected (Fig. 2). For the second period (2071-2100) the increase of drought hazard will be more intensive. In the majority of the areas the rate of increase will be in the $25-50 \%$ intervals.

The ALADIN model simulation shows similar trends, however, this model projects more intensive increase of the drought hazard. For 2021-2050 most of the Great Hungarian Plain (96\%) will be affected by a 10-30\% increase of drought hazard. For 2071-2100 the drought hazard will be more serious. On $96 \%$ of the arable lands the rate of change will be between $35-60 \%$ on the basis of the climate models.

In the spatial pattern of the drought hazard noticeable differences can be observed in the reference period (1961-1990). The least drought hazard occurred in the northeastern part of the Great Hungarian Plain, while the center part was affected by the highest drought hazard (Fig. 2). Based on the climate model simulation data, the increase of the drought hazard is expected in the whole study area. For the period of 2071-2100 the highest increase is expected in the same areas (central part of the Great Hungarian Plain), where the highest drought hazard was observed in the reference period. The lowest increase is projected for the same area (northeastern part of the Great Hungarian Plain), where the least drought hazard was observed in the reference period (Fig. 2). Thus the spatial differences in the rate of drought hazard will become more pronounced.

\subsection{Changes in Wind Erosion Hazard}

The wind erosion hazard is expected to change differently than the drought hazard and its uncertainty is higher, since the changes are not as obvious and the two models show different results (Table 2). Slightly increasing wind erosion hazard $(2 \%)$ is projected by both the ALADIN and REMO model simulations for the second period. However, no increase is projected for the first period by ALADIN model simulations, while REMO projects a higher increase for the 2021-2050 period $(7 \%)$ than for the second period $(2 \%)$. Extreme negative values $(<-10 \%)$ and positive values $(>15 \%)$ are excluded by normalization for the further analysis.

After normalization, the rate of changes varied between -10 and $15 \%$ in the first period (2021-2050) and -5 and $5 \%$ in the second period (2071-2100). In the first period
Table 2 Changes (\%) of drought, wind erosion, and inland excess water hazards for two future periods compared to 1961-1990 on arable lands on the Great Hungarian Plain

\begin{tabular}{|c|c|c|c|c|}
\hline \multirow{2}{*}{$\begin{array}{l}\text { Investigated } \\
\text { hazards }\end{array}$} & \multirow{2}{*}{$\begin{array}{l}\text { Modelled } \\
\text { Periods }\end{array}$} & \multicolumn{3}{|c|}{ Change (\%) } \\
\hline & & Minimum & Maximum & Average \\
\hline \multirow[t]{4}{*}{ Drought hazard } & $\begin{array}{l}\text { ALADIN } \\
\text { 2021-2050 }\end{array}$ & -0.07 & 29.79 & 19.99 \\
\hline & $\begin{array}{l}\text { ALADIN } \\
2071-2100\end{array}$ & 0.00 & 64.00 & 45.21 \\
\hline & $\begin{array}{l}\text { REMO } \\
2021-2050\end{array}$ & -0.14 & 23.04 & 12.27 \\
\hline & $\begin{array}{l}\text { REMO } \\
2071-2100\end{array}$ & 0.00 & 56.37 & 35.57 \\
\hline \multirow[t]{4}{*}{$\begin{array}{l}\text { Wind erosion } \\
\text { hazard }\end{array}$} & $\begin{array}{l}\text { ALADIN } \\
\text { 2021-2050 }\end{array}$ & -56.39 & 69.85 & 0.08 \\
\hline & $\begin{array}{l}\text { ALADIN } \\
2071-2100\end{array}$ & -56.39 & 70.01 & 2.47 \\
\hline & $\begin{array}{l}\text { REMO } \\
2021-2050\end{array}$ & -56.39 & 73.71 & 7.22 \\
\hline & $\begin{array}{l}\text { REMO } \\
2071-2100\end{array}$ & -56.39 & 69.85 & 2.02 \\
\hline \multirow[t]{4}{*}{$\begin{array}{l}\text { Inland excess } \\
\text { water hazard }\end{array}$} & $\begin{array}{l}\text { ALADIN } \\
\text { 2021-2050 }\end{array}$ & -1.18 & 0.00 & -0.67 \\
\hline & $\begin{array}{l}\text { ALADIN } \\
2071-2100\end{array}$ & -4.07 & 0.00 & -1.65 \\
\hline & $\begin{array}{l}\text { REMO } \\
2021-2050\end{array}$ & -2.55 & 0.00 & -1.57 \\
\hline & $\begin{array}{l}\text { REMO } \\
2071-2100\end{array}$ & -1.09 & 1.42 & -0.11 \\
\hline
\end{tabular}

the models show quite different trends of changes (REMO model simulation data show higher differences $(-5$ and $15 \%)$ than ALADIN model simulation data $(-10$ and $0 \%)$. According to the ALADIN model, on $83 \%$ of the arable land an insignificant decrease $(-5$ to $0 \%)$ in wind erosion hazard is projected. On the basis of the REMO model, decrease of the hazard is modeled only on $6 \%$ of the area, while half of the area (49\%) will be affected by more than $10 \%$ increase in the hazard.

In the period of 2071-2100, according to the REMO model, the wind erosion hazard will decrease back to a similar rate as in the reference period (1961-1990). Only minor changes were modeled, since $74 \%$ of the arable lands were in the interval of -5 and $0 \%$ and $21 \%$ in the interval of 0 and $5 \%$ (Fig. 3) and the ALADIN model simulation shows the same trend for this period.

The spatial pattern of the hazard is largely affected by the erodibility of the soil. Thus the highest wind erosion hazard was identified in the northeastern and middle parts of the study area, the sandy areas in the Great Hungarian Plain (Lóki 2011). Based on the climate model simulation data, a slight change of the wind erosion hazard is expected in most parts of the area. For the period 2071-2100, the 


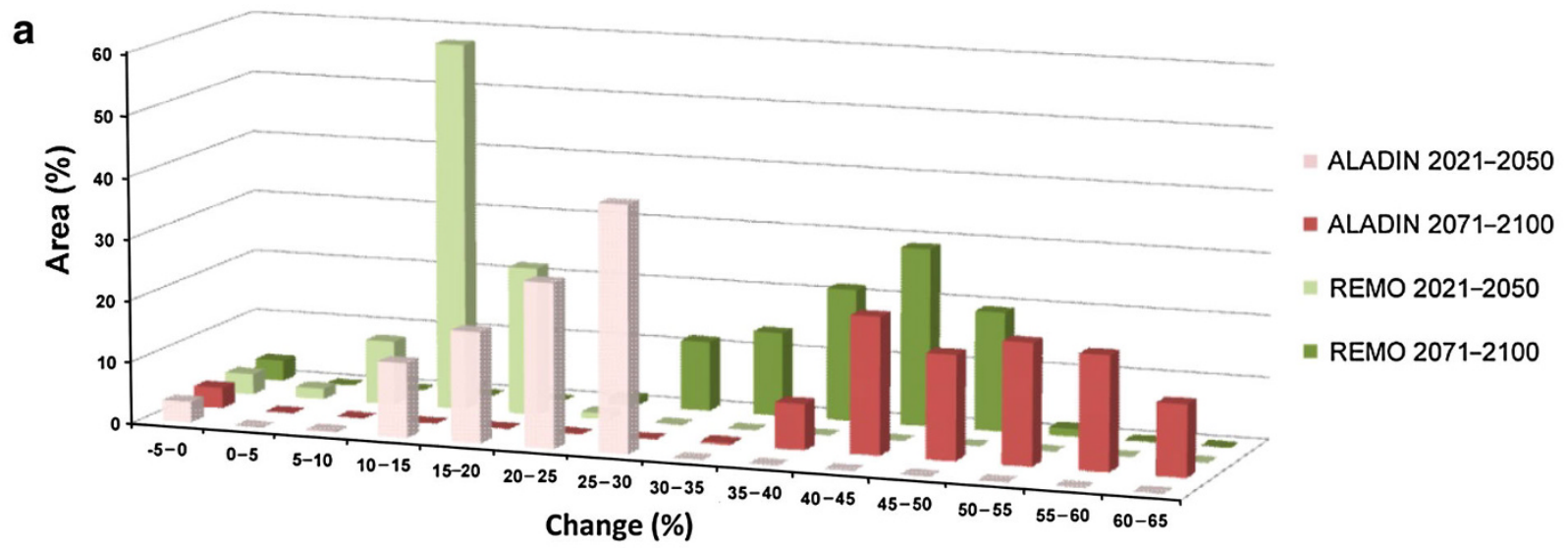

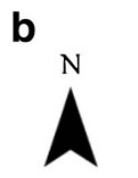

1961-1990

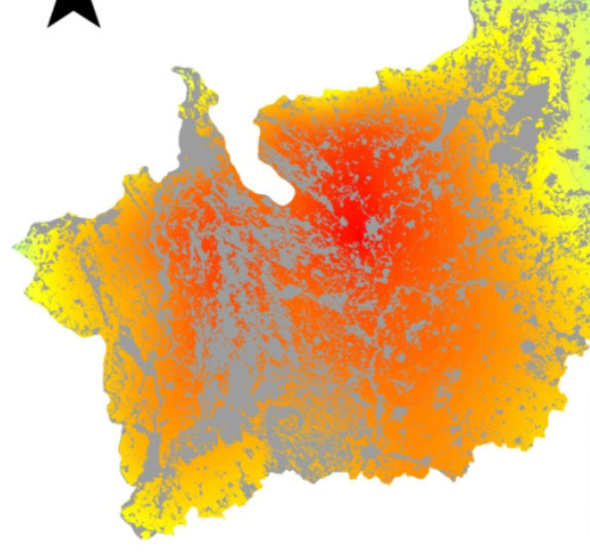

0

$100 \mathrm{Km}$

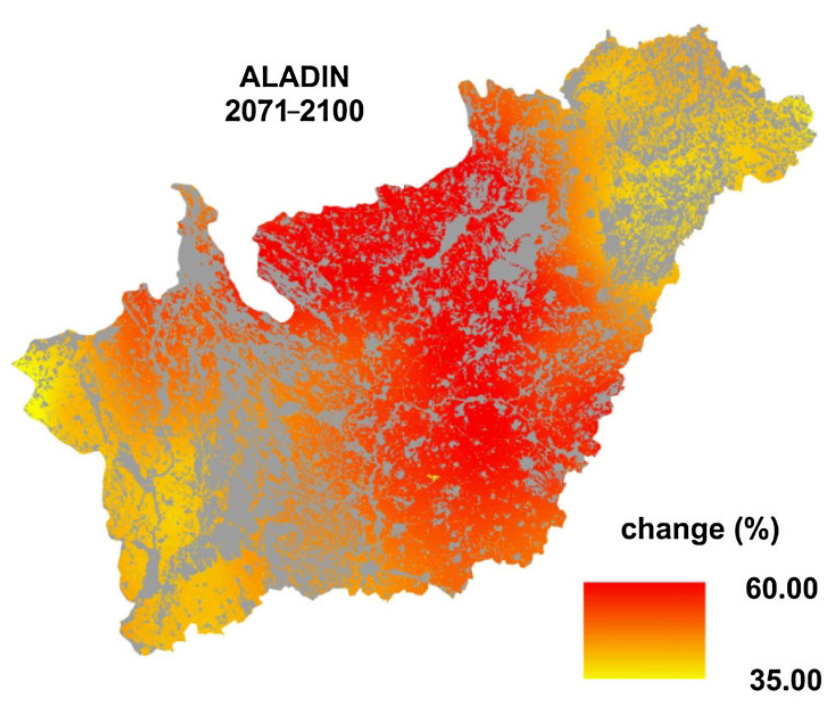

3.06

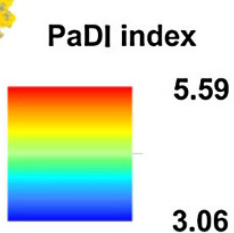

pastures, forests, permanent crops, wetlands, water bodies, artificial surfaces
Fig. 2 The area of arable lands (\% compared to the total arable lands) in $5 \%$-intervals of the changes of drought hazard between 1961-1990 and the two future periods based on ALADIN and REMO

highest increase is expected in the southeastern part, due to the significant changes of the climate parameters (Fig. 3).

\subsection{Changes in Inland Excess Water Hazard}

The occurrence of inland excess water is influenced by many local factors, thus the uncertainty of the future projection is quite high. The increase of evapotranspiration and the significant decrease in the number of frost days can decrease the formation of inland excess waters, while due to intensive precipitation events, summer and autumn inundations can increase (Nováky 2011). Beside the high uncertainty, the changes of the hazard, calculated on the basis of climate parameters are not significant (between -4 and $0 \%$ ). Only a slight decrease of this hazard can be expected in the future (Table 2). models (a); drought hazard on arable lands on the Great Hungarian Plain in the reference period (1961-1990) and its changes (\%) for the future period of 2071-2100 based on ALADIN model simulation (b)

Based on ALADIN model simulations HUMI values will not significantly change in both future periods (Fig. 4). The ALADIN climate model simulation shows less than $5 \%$ decrease for both future periods. For the first period (2021-2050), REMO model simulation data indicate the same rate and direction of the changes. However, REMO projects differently for the period of 2071-2100, where a slight increase is projected in some areas.

In the reference period (1961-1991) the highest inland water hazard was observed in the northeastern part of the study area on the basis of the HUMI index (Fig. 4). The lowest values were experienced in the central part of the Great Hungarian Plain. However, the differences of the values are not high and vary between 1.03 and 1.18 . For the period of 2071-2100, on the basis of the ALADIN climate model simulation, the inland excess water hazard, indicated 
a

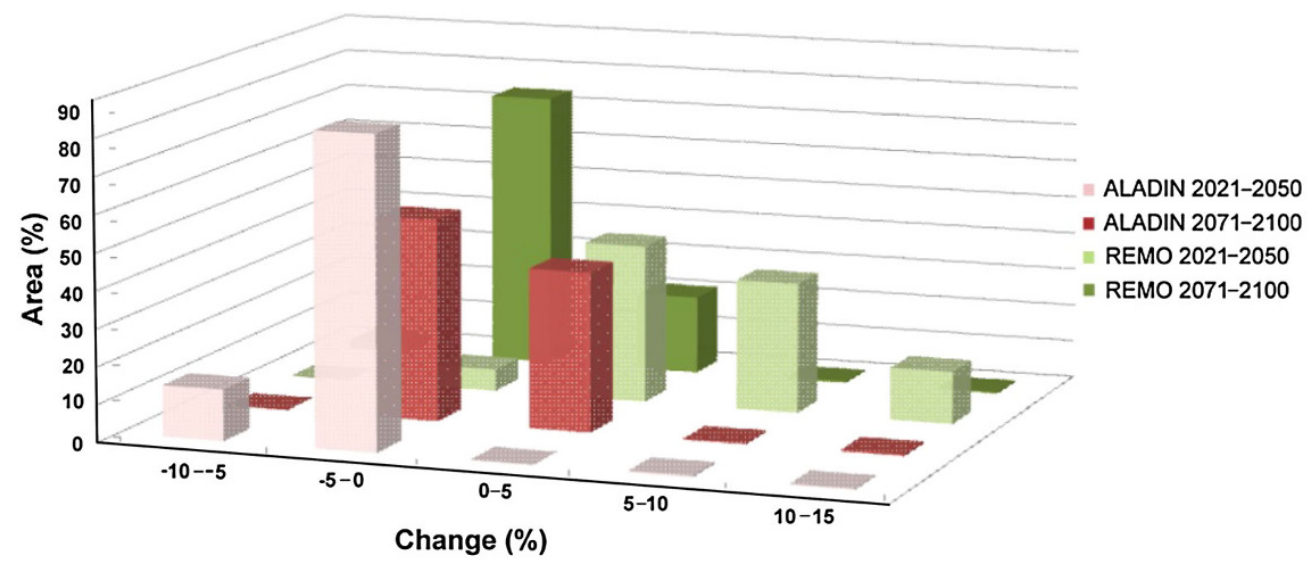

$\stackrel{\text { b }}{N}$

$1961-1990$
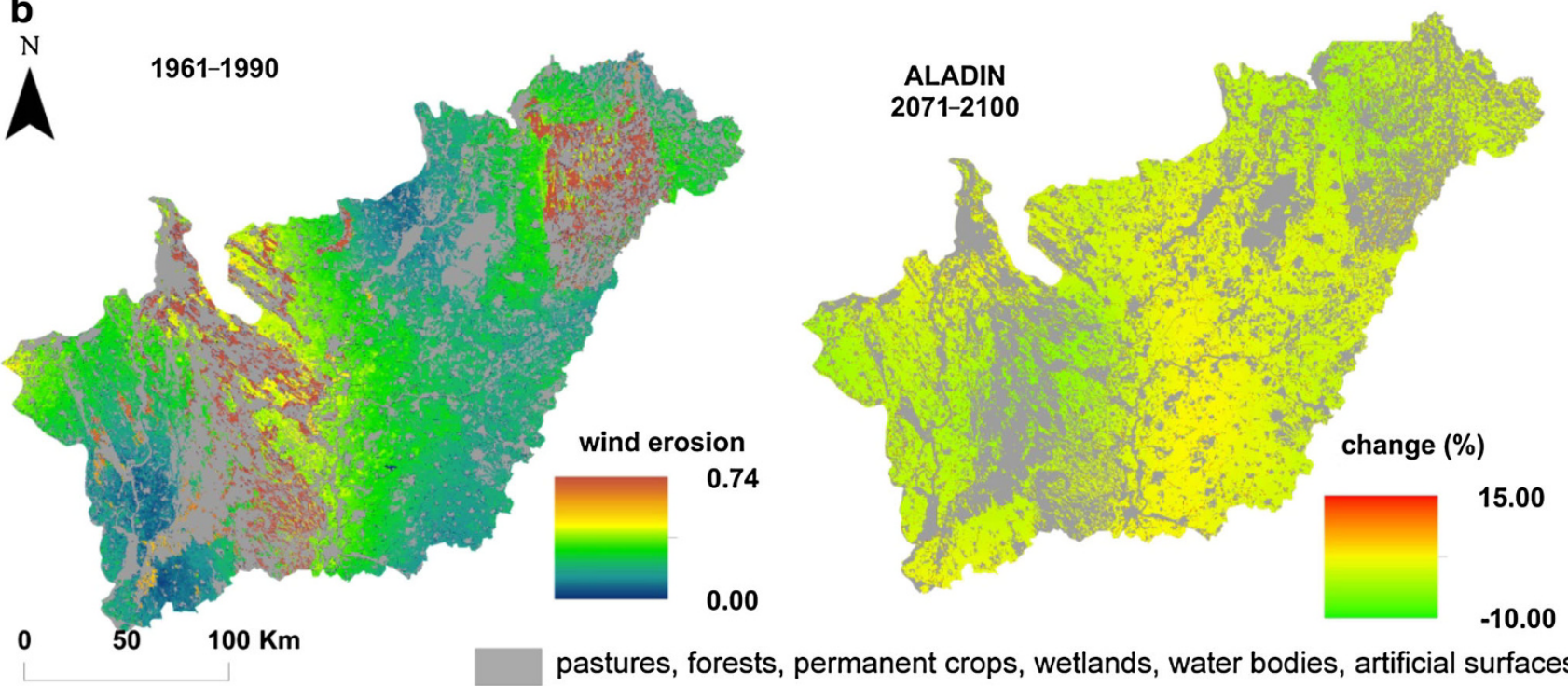

pastures, forests, permanent crops, wetlands, water bodies, artificial surfaces

Fig. 3 The area of arable lands (\% compared to the total arable lands) in $5 \%$-intervals of the changes of wind erosion hazard between 1961-1990 and the two future periods based on ALADIN and REMO models (a); wind erosion hazard on arable lands on the Great

by the HUMI index is expected to slightly decrease in the whole area. The most intensive, but very minor decrease of the hazard is expected in the northeastern part of the area, where the hazard was the highest in the reference period. The most insignificant changes are projected for the southern part of the area.

\section{Discussion}

Based on the assessment, increasing natural hazards are projected on arable lands for the analyzed future periods. Among the investigated natural hazards, the drought hazard is the most significant problem of the region, since $42 \%$ of the damage incurred in Hungarian agriculture is caused by drought alone (AKI 2013). The increase of the drought
Hungarian Plain in the reference period (1961-1990) and its changes (\%) for the future period of 2071-2100 based on ALADIN model simulation (b)

hazard is expected to be the most obvious and most intensive in the twenty-first century. For the period of 2071-2100 the increase of the drought hazard is projected to exceed $40 \%$ on half of the arable lands on the basis of REMO, while ALADIN projects an even more intensive increase. Drought most likely will be the most serious problem of the region in the future. Wind erosion hazard is also expected to increase slightly and the spatial variation of the hazard highly corresponds to soil properties. However, the extension and seriousness of this hazard is lower nowadays and it will remain lower in the future than the drought hazard, because the effect of wind erosion is more local, and the increase of this hazard is not as obvious as in the case of the drought hazard. The changes of the wind erosion hazard are expected to be less intensive for the analyzed periods. The calculated changes remain below 
a

b
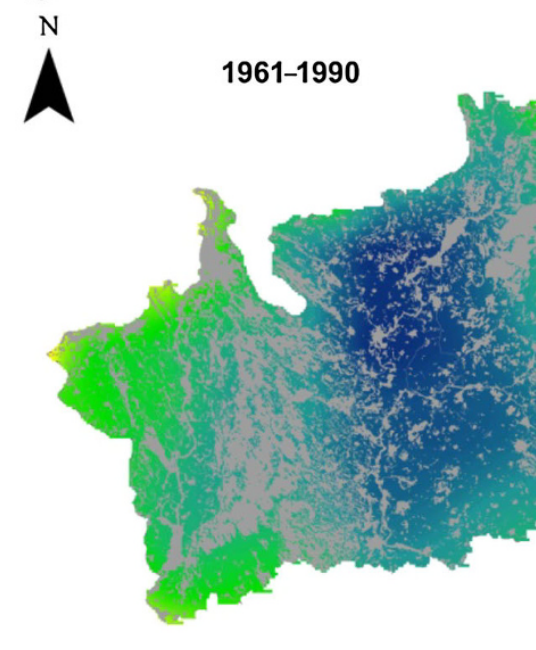

0

50

$100 \mathrm{Km}$

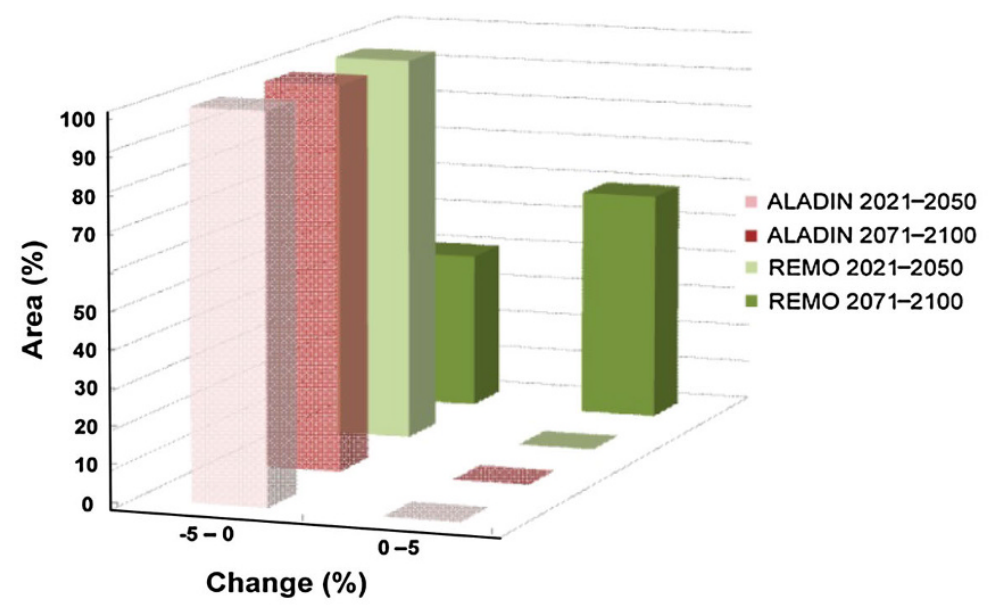

Fig. 4 The area of arable lands (\% compared to the total arable lands) in $5 \%$-intervals of the changes of inland excess water hazard between 1961-1990 and the two future periods based on ALADIN and REMO models (a); inland excess water hazard on arable lands on

$10 \%$ for most of the area, which does not indicate a major alteration of the hazard.

The assessment of the effect of climate change on the inland excess water hazard is the most difficult problem among the analyzed hazards, because inland excess water is a complex phenomenon and for the future periods the slightest and less obvious changes were observed in the case of this natural hazard. The importance of this hazard will be similar to what it was in the reference period (1961-1990). However, due to its complexity and local influencing factors the future projection has high uncertainty. Changes of the inland excess water hazard are hard to estimate, because the projected groundwater decrease, the 10-20\% decrease in annual mean runoff, the increasing winter precipitation, and the overall decrease of available water resources have contradictory effects (Nováky 2011). This uncertainty is

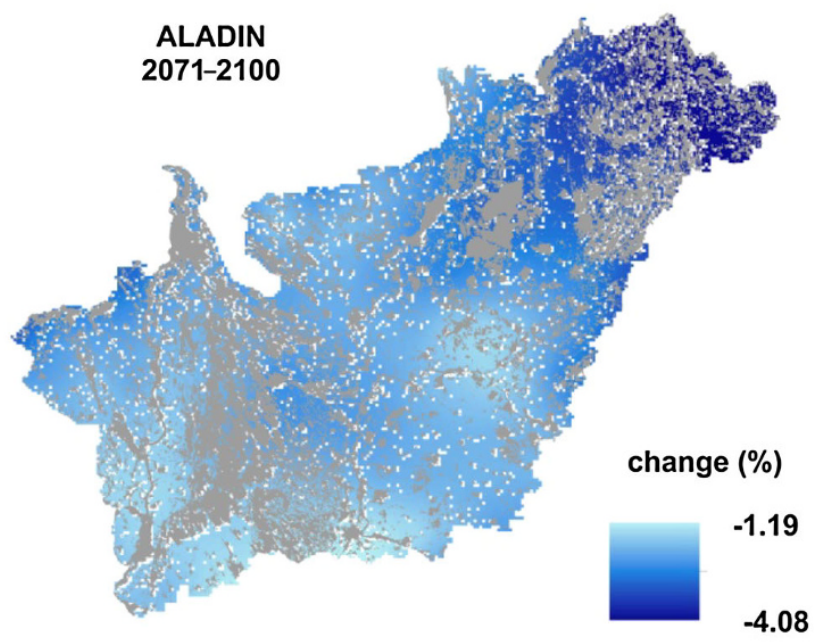

$-4.08$ the Great Hungarian Plain in the reference period (1961-1990) and its changes (\%) for the future period of 2071-2100 based on ALADIN model simulation (b)

particularly valid for the inland excess water occurrence in the winter half year, when the increase of evapotranspiration and the significant decrease in the number of frost days can decrease the formation of inland excess waters. In the summer half year, however, due to the more probable increase of intensive precipitation events, inundations can increase (Nováky 2011). In the regional climate model simulations the winter precipitation projection has the highest uncertainty (Bartholy et al. 2011). Thus it influences HUMI values, increasing the uncertainty of inland excess water assessment. But inland excess water does not necessarily imply damage: in a drying environment it can have an important role in the recharge of the diminishing subsurface water reservoirs.

Despite the low differences in relief and the climate conditions of the study area, spatial differences were 
observed. The central and southern parts of the study area seem to be the most affected by all investigated hazards in the future. In this area the increase of drought and wind erosion hazards is expected to be the highest and the decrease of the inland water hazard is the lowest.

\section{Conclusion}

In the twenty-first century arable lands on the Great Hungarian Plain will face increasing environmental hazards owing to the unfavorable trends of the climate change on the basis of regional climate model simulations (REMO and ALADIN). The most important change is the intensive increase of the drought hazard, which makes this hazard probably the most serious hazard of the region. The changes in wind erosion and inland excess water hazards show less definite trends. However, because of the projected increase in climatic extremes (Bartholy et al. 2011), the 30-year average value can conceal high fluctuation in the hazards. As a consequence of the increasing climatic extremes, years will probably occur, when the rate of the wind erosion or inland excess water hazard will increase.

The present assessment has several uncertainties that influence the calculations. These uncertainties originate from the incalculable small-scale environmental conditions and also from the climate models. The uncertainty of the climate projection is caused by many factors. Some arise from the modeling method and the natural climate variability. However, modeling the social and economic changes in the future (the anthropogenic climate forcing factor in the models) is the most difficult and therefore the most uncertain part of the models. The uncertainty of the climate model simulation results can hardly decrease due to the lack of validation of the modeling data (Bartholy et al. 2008).

Applying more climate models (for example REMO and ALADIN) simultaneously and scenarios beside A1B in an assessment is favorable, because in this way the rate of uncertainty can be determined more precisely. Despite these limitations, the present assessment can provide valuable data for several sectors of society, where there will be an increased need for a long-term perspective on the exposure to natural hazards.

The assessment can provide information about the future changes of natural hazards for agriculture and spatial planning. The results can help the decision-making process about short-term and long-term adaptation measures to mitigate the consequences. The different types of hazards require different adaptation practices, such as changing agricultural techniques (for example, tillage in adequate time and way according to the soil characteristic, water efficient irrigation, shelter belts) or even land use changes such as conversion of arable land to pasture. In the long term prevention of natural disasters can be achieved by the development of early warning systems, for example, similar to the Multi-Hazard Early Warning Systems in the United States or land use changes. In the short term, prevention can be achieved by changing agricultural techniques and crops, such as adopting drought-tolerant species.

Open Access This article is distributed under the terms of the Creative Commons Attribution License which permits any use, distribution, and reproduction in any medium, provided the original author(s) and the source are credited.

\section{References}

AKI (Research Institute of Agricultural Economics). 2013. Agrárgazdasági Kutató Intézet. https://www.aki.gov.hu (in Hungarian). Accessed 28 Mar 2014.

Bakonyi, P. 2010. Flood and drought strategy of the Tisza River Basin. VITUKI, Budapest. http://www.icpdr.org/main/resources/ flood-and-drought-mitigation-strategy-tisza-river-basin. Accessed 28 Mar 2014.

Bartholy, J., R. Pongrácz, G. Gelybó, and P. Szabó. 2008. Analysis of expected climate change in the Carpathian Basin using the PRUDENCE results. Idöjárás Quarterly Journal of the Hungarian Meteorological Service 112(3-4): 249-264.

Bartholy, J., R. Pongrácz, I. Pieczka, and C.S. Torma. 2011. Dynamical downscaling of projected 21st century climate for the Carpathian Basin. In Climate change-Research and technology for adaptation and mitigation, ed. J. Blanco, and $\mathrm{H}$. Kheradmand, 3-22. Rijeka: InTech.

Bihari, Z. (ed.). 2012. Drought Management Centre for South-East Europe. Budapest: OMSZ. http://www.met.hu/doc/DMCSEE/ DMCSEE_final_publication.pdf. Accessed 28 Mar 2014.

Blanka, V., G. Mezősi, and B. Meyer. 2013. Projected changes in the drought hazard in Hungary due to climate change. Idójárás Quarterly Journal of the Hungarian Meteorological Service 117(2): 219-237.

Bozán, C., J. Körösparti, L. Pásztor, L. Kuti, P. Kozák, and I. Pálfai. 2009. GIS-based mapping of excess water inundation hazard in Csongrád County (Hungary). In Proceedings of the international symposia on risk factors for environment and food safety \& natural resources and sustainable development, 678-684. Faculty of Environmental Protection, Oradea, 6-7 November 2009.

Fratini, G., M. Santini, P. Ciccioli, and R. Valentini. 2009. Evaluation of a wind erosion model in a desert area of northern Asia by eddy covariance. Earth Surface Processes and Landforms 34(13): $1743-1757$.

Fryrear, D.W., A. Saleh, J.D. Bilbro, H.M. Schomberg, J.E. Stout, and T.M. Zobeck. 1998. Revised wind erosion equation (RWEQ). Wind Erosion and Water Conservation Research Unit, Technical Bulletin 1. Southern Plains Area Cropping Systems Research Laboratory, USDA-ARS. http://www.csrl.ars.usda.gov/wewc/ rweq/app.pdf. Accessed 28 Mar 2014.

Funk, R., C. Hoffmann, and M. Reiche. 2004. Methods for quantifying wind erosion in steppe regions. In Novel measurement and assessment tools for monitoring and management of land and water resources in agricultural landscapes of Central Asia, ed. L. Mueller, A. Saparov, and G. Lischeid, 315-327. Switzerland: Springer International Publishing. 
Gosic, M., and S. Trajkovic. 2013. Analysis of precipitation and drought data in Serbia over the period 1980-2010. Journal of Hydrology 494: 32-42.

Hagen, L.J. 2004. Evaluation of the wind erosion prediction system (WEPS) erosion submodel on cropland fields. Environmental Modelling and Software 19(2): 171-176.

Hazafi, L. 2003. Drought in 1.5 million hectares. World Economy (Világgazdaság). http://www.vg.hu/gazdasag/aszalykar-15millio-hektaron-35006 (in Hungarian). Accessed 28 Mar 2014.

HCSO (Hungarian Central Statistical Office). 2011. Environmental report, 2011. Hungarian Central Statistical Office, Budapest. https://www.ksh.hu/docs/eng/xftp/idoszaki/ekornyhelyzetkep11. pdf. Accessed 28 Mar 2014.

HMS (Hungarian Meteorological Service). 2013. Országos Meteorológiai Szolgálat. http://www.met.hu/. Accessed 28 Mar 2014.

IPCC (Intergovernmental Panel on Climate Change). 2007. Climate change. The physical science basis. Working Group I. Contribution to the fourth assessment report of the IPCC, ed. S. Solomon, D. Qin, M. Manning, Z. Chen, M. Marquis, K.B. Averyt, M. Tignor, and H.L. Miller. New York: Cambridge University Press.

Julian, J.P., R.J. Davies-Colley, C.L. Gallegos, and T.V. Tran. 2013. Optical water quality of inland waters: A landscape perspective. Annals of the Association of American Geographers 103(2): 309-318.

Klik, A. 2004. Wind erosion assessment in austria using wind erosion equation and GIS. In Agricultural impacts on soil erosion and soil biodiversity: Developing indicators for policy analysis, ed. R. Francaviglia, 145-154. Rome: Proceedings from an OECD expert meeting.

Lei, Y.D., J.A. Wang, and L.L. Luo. 2011. Drought risk assessment of China's mid-season paddy. International Journal of Disaster Risk Science 2(2): 32-40.

Li, F.R., L.F. Kang, H. Zhang, L.Y. Zhao, Y. Shirato, and I. Taniyama. 2005. Changes in intensity of wind erosion at different stages of degradation development in grasslands of Inner Mongolia, China. Journal of Arid Environments 62(4): 567-585.

Likens, G.E. (ed.). 2009. Encyclopedia of inland waters. Oxford: Elsevier/Academic Press.

Lin, Y.Z., X.Z. Deng, and Q. Jin. 2013. Economic effects of drought on agriculture in North China. International Journal of Disaster Risk Science 4(2): 59-67.

Lóczy, D., Á. Kertész, J. Lóki, T. Kiss, P. Rózsa, G. Sipos, L. Sütő, J. Szabó, and M. Veress. 2012. Recent landform evolution in Hungary. In Recent landform evolution, ed. D. Lóczy, M. Stankoviansky, and A. Kotarba, 205-247. New York: Springer.

Lóki, J. 2011. Research of the land forming activity of wind and protection against wind erosion in Hungary. Riscuri Si Catastrofe 9(1): 83-97.

Maracchi, G. 2000. Agricultural drought-A practical approach to definition, assessment and mitigation strategies. In Drought and drought mitigation in Europe. Advances in natural and technological hazards research 14, ed. J.V. Vogt, and F. Somma, 63-78. Dordrecht: Kluwer Academic Publisher.

Meyer, B.C., S. Rannow, S. Greiving, and D. Gruehn. 2009. Regionalisation of climate change impacts in Germany for the usage in spatial planning. GeoScape 1: 34-43.

Mezősi, G. 2011. Environmental capabilities, hazards and conflicts in Hungary. Szeged: UNIV Kiadó.

Mezősi, G., V. Blanka, T. Bata, F. Kovács, and B. Meyer. 2013. Estimation of regional differences in wind erosion sensitivity in Hungary. Natural Hazards and Earth System Sciences Discussion 1: 4713-4750.

Mezősi, G., B.C. Meyer, W. Loibl, C. Aubrecht, P. Csorba, and T. Bata. 2013. Assessment of regional climate change impacts on
Hungarian landscapes. Regional Environmental Change 13(4): $797-811$.

Munson, S.M., J. Belnap, and G.S. Okin. 2011. Responses of wind erosion to climate-induced vegetation changes on the Colorado Plateau. Proceedings of the National Academy of Sciences of the United States of America 108(10): 3854-3859.

Nakicenovic, N., and R. Swart (ed.). 2000. Emissions scenarios. A special report of IPCC Working Group III. Cambridge: Cambridge University Press.

Nováky, B. 2011. Climate change and its consequences (Az éghajlatváltozás és hatásai). In Water management in Hungary: Current situation and strategic issues (Magyarország vízgazdálkodása: Helyzetkép és stratégiai feladatok), ed. L. Somlyódy, 85-102. Budapest: MTA (in Hungarian).

Pálfai, I. 2002. Probability of drought occurrence in Hungary. Idöjárás Quarterly Journal of the Hungarian Meteorological Service 106(3-4): 265-275.

Pálfai, I. 2004. Inland excess water and drought in Hungary (Belvízek és Aszályok Magyarországon). Budapest: VITUKI (in Hungarian).

Pálfai, I., and Á. Herceg. 2011. Droughtness of Hungary and Balkan Peninsula. Riscuri si Catastrofe 9(2): 145-154.

Péczely, G. 1998. Climatology (Éghajlattan). Budapest: Nemzeti Tankönykiadó (in Hungarian).

Rakonczai, J., A. Farsang, G. Mezősi, and N. Gál. 2011. The conceptual background of the formation of inland excess water. Földrajzi Közlemények 135(4): 339-349 (in Hungarian).

Shao, Y.P., E. Jung, and L.M. Leslie. 2002. Numerical prediction of northeast Asian dust storms using an integrated wind erosion modeling system. Journal of Geophysical Research: Atmospheres 107(D24): AAC 21-1-23.

Shi, K., Y.M. Li, L. Li, and H. Lu. 2013. Absorption characteristics of optically complex inland waters: Implications for water optical classification. Journal of Geophysical Research G: Biogeosciences 118(2): 860-874.

Sterk, G. 2003. Causes, consequences and control of wind erosion in Sahelian Africa: A review. Land Degradation and Development 14(1): 95-108.

Svoboda, M., D. LeComte, M. Hayes, R. Heim, K. Gleason, J. Angel, B. Rippey, R. Tinker, et al. 2002. The drought monitor. Bulletin of the American Meteorological Society 83: 1181-1190.

Szabó, L., J. Karácsony, and Z.S. Székely. 1994. Wind erosion problems in Hungary. Agrochemistry and Soil Science 43(1-2): $109-112$.

Szabó, J., J. Lóki, C. Tóth, and G. Szabó. 2008. Natural hazards in Hungary. In Dimensions and trends in Hungarian geography, ed. Á. Kertész, and Z. Kovács, 55-68. Budapest: MTA.

Szabó, P., A. Horányi, I. Krüzselyi, and G. Szépszó. 2011. The climate modelling at Hungarian Meteorological Survey: ALADIN and REMO. Budapest: OMSZ (in Hungarian).

Széll, E., and K. Dévényi. 2008. Average yield in 2007-Reasons and lessons in maize cultivation. Agro Napló 12(1): 1-7 (in Hungarian).

Thornthwaite, C.W. 1948. An approach toward a rational classification of climate. Geographical Review 38(1): 55-94.

Toure, A.A., J.L. Rajot, Z. Garba, B. Marticorena, C. Petit, and D. Sebag. 2011. Impact of very low crop residues cover on wind erosion in the Sahel. CATENA 85(3): 205-214.

van Leeuwen, B. 2012. Artificial neural networks and geographic information systems for inland excess water classification. Ph.D. dissertation, University of Szeged, Hungary.

Warrick, R.A., P.B. Trainer, E.J. Baker, and W. Brinkman. 1975. Drought hazard in the United States: A research assessment. NSF program on technology, environment and man monograph. Institute of Behavioral Science, University of Colorado.

Webb, N.P., H.A. McGowan, S.R. Phinn, and G.H. McTainsh. 2006. AUSLEM (Australian Land Erodibility Model): A tool for 
identifying wind erosion hazard in Australia. Geomorphology 78(3-4): 179-200.

WMO (World Meteorological Organization), UNCCD (United Nations Convention to Combat Desertification), FAO (Food and Agriculture Organization of the United Nations), and UNWDPC (UN-Water Decade Programme on Capacity Development). 2013. Country report: Drought conditions and management strategies in Serbia. Initiative of "Capacity development to support national drought management policy". http://www.ais.
unwater.org/ais/pluginfile.php/548/mod_page/content/65/Ser bia_CountryReport.pdf. Accessed 28 Mar 2014.

Woodruff, N.P., and F.H. Siddoway. 1965. A wind erosion equation. Soil Science Society of America Journal 29(5): 602-608.

Ye, T., P.J. Shi, J.A. Wang, L. Liu, Y. Fan, and J. Hu. 2012. China's drought disaster risk management: Perspective of severe droughts in 2009-2010. International Journal of Disaster Risk Science 3(2): 84-97.

Zeng, N. 2003. Drought in the Sahel. Science 302(5647): 999-1000. 